\title{
EXOGENOUS LOW-DOSE HYDROGEN PEROXIDE ENHANCES DROUGHT TOLERANCE OF SOYBEAN (GLYCINE MAX L.) THROUGH INDUCING ANTIOXIDANT SYSTEM
}

\author{
Neslihan Saruhan Guler ${ }^{1 *}$ and Necla Pehlivan ${ }^{2}$ \\ ${ }^{1}$ Department of Nutrition and Dietetics, Faculty of Health Sciences, Karadeniz Technical University, \\ 61080, Trabzon, Turkey \\ ${ }^{2}$ Department of Biology, Faculty of Arts and Sciences, Recep Tayyip Erdogan University, \\ 53100, Rize, Turkey
}

(Received: July 31, 2015; accepted: November 24, 2015)

\begin{abstract}
Hydrogen peroxide $\left(\mathrm{H}_{2} \mathrm{O}_{2}\right)$ functions as a signal molecule in plants under abiotic and biotic stress. In this study, the role of exogenous $\mathrm{H}_{2} \mathrm{O}_{2}$ in improving drought tolerance in two soybean cultivars (Glycine max L. Merrill) differing in their tolerance to drought was evaluated. Plants were grown in plastic pots with normal irrigation in a phytotron. Four weeks after radicle emergence, either $1 \mathrm{mM} \mathrm{H}_{2} \mathrm{O}_{2}$ or distilled water was sprayed as foliar onto the leaves of each plant, after drought stress was applied. Leaf samples were harvested on the $4^{\text {th }}$ and $7^{\text {th }}$ days of the drought. Antioxidant-related enzyme activity, such as the superoxide dismutase (SOD), catalase (CAT), ascorbate peroxidase (APX), glutathione reductase (GR), monodehydroascorbate reductase (MDHAR), dehydroascorbate reductase (DHAR), hydrogen peroxide $\left(\mathrm{H}_{2} \mathrm{O}_{2}\right)$ and malondialdehyde (MDA) content was measured during the drought period. Drought stress decreased leaf water potential, relative water content and photosynthetic pigment content but enhanced lipid peroxidation and endogenous $\mathrm{H}_{2} \mathrm{O}_{2}$ concentration. By contrast, exogenous low dose $\mathrm{H}_{2} \mathrm{O}_{2}$ improved water status, pigment content and lipid peroxidation under drought stress. Endogenous $\mathrm{H}_{2} \mathrm{O}_{2}$ concentration was reduced by exogenous $\mathrm{H}_{2} \mathrm{O}_{2}$ as compared to drought treatment alone. $\mathrm{H}_{2} \mathrm{O}_{2}$ pre-treatment induced all the antioxidant enzyme activities, to a greater extent than the control leaves, during drought. $\mathrm{H}_{2} \mathrm{O}_{2}$ pretreatment further enhanced the activities of antioxidant enzymes in the tolerant cultivar compared to the sensitive cultivar. Results suggested that low dose $\mathrm{H}_{2} \mathrm{O}_{2}$ pre-treatment alleviated water loss and $\mathrm{H}_{2} \mathrm{O}_{2}$ content and increased drought stress tolerance by inducing the antioxidant system.
\end{abstract}

Keywords: Hydrogen peroxide - Gylcine max L. - drought tolerance - antioxidant enzymes

\section{INTRODUCTION}

Plants are constantly encountered by various abiotic stresses that negatively affect growth and productivity worldwide [15]. Drought stress is the primary cause of crop loss across the globe, reducing average yields in most major crop plants. A common effect of drought stress, as with other environmental stresses, is oxidative damage. Exposure to drought results in a loss of balance between the production of reactive oxygen species (ROS), such as superoxide $\left(\mathrm{O}_{2}{ }^{-}\right)$, hydrogen peroxide $\left(\mathrm{H}_{2} \mathrm{O}_{2}\right)$, hydroxyl radicals $\left({ }^{\circ} \mathrm{OH}\right)$ and singlet oxygen $\left({ }^{\circ} \mathrm{O}_{2}\right)$ and their scavenging potential [31].

\footnotetext{
*Corresponding author; e-mail address: neslihansaruhan@hotmail.com
} 
Overproduction of ROS is a common phenomenon in plants under biotic and abiotic stress conditions, which can cause oxidative damage to macromolecules and cell structures, leading to inhibition of plant growth and development, or even to death. Among all ROS, $\mathrm{H}_{2} \mathrm{O}_{2}$ acts as a central player in stress signal transduction pathways associated with tolerance to abiotic and biotic stresses [15]. Furthermore, $\mathrm{H}_{2} \mathrm{O}_{2}$ directly regulates the expression of numerous genes involved in plant defense and the related pathways such as antioxidant enzymes, defense proteins and transcription factors [16]. Several recent studies have demonstrated that exogenous $\mathrm{H}_{2} \mathrm{O}_{2}$ can enhance abiotic stress tolerance either by modulating ROS detoxification or regulating multiple stress-responsive pathways and gene expression [1, 15, 21, 33]. Ishibashi et al. [17] showed that exogenous application of $\mathrm{H}_{2} \mathrm{O}_{2}$ promotes the up-regulation of stress responsive genes and increases drought stress tolerance. Lately a micro-array study indicated that the expression level of several hundred genes altered in $\mathrm{H}_{2} \mathrm{O}_{2}$ treated Arabidopsis cell cultures [7]. Another effect of $\mathrm{H}_{2} \mathrm{O}_{2}$ is its capacity to induce the expression of transcription factors and genes responsible for osmolyte synthesis such as proline and betaine, and activate phosphorylation cascades using mitogen-activated protein kinases (MAPKs) [15]. Terzi et al. [33] found that exogenous $\mathrm{H}_{2} \mathrm{O}_{2}$ pretreatment induced osmotic stress tolerance by increasing soluble sugar, proline, and polyamine levels in maize (Zea mays L.) seedlings. Liu et al. [23] also reported that $\mathrm{H}_{2} \mathrm{O}_{2}$ pre-treatment of two cucumber varieties improved osmotic stress resistance by activating antioxidant system. Abass and Mohamed [1] also studied the effects of $\mathrm{H}_{2} \mathrm{O}_{2}$ pre-treatment on the seeds of common bean seedlings (Phaseolus vulgaris L.) and analyzed drought tolerance in seedlings.

Soybean has been known as one of the major legume crops in the world, providing an abundant source of oil and protein-rich food for both human and animal consumptions. However, soybean growth, development, and yield are greatly affected by several abiotic stressors, such as flooding [19], drought [24], and salinity [32]. Particularly, in soybeans, drought stress occurring at the early stage of pod development significantly increases the rate of pod abortion, thus decreasing final seed yield [22]. As can be seen from literature although several studies report strategies to improve drought tolerance, little information is available on the antioxidative and physiological mechanism of low dose $\mathrm{H}_{2} \mathrm{O}_{2}$-induced drought stress alleviation in plants. In the present study, we hypothesize that low dose of $\mathrm{H}_{2} \mathrm{O}_{2}$ can reduce adverse effects of drought stress by inducing antioxidant systems and decreasing ROS level in plants. At the same time, this approach assumes great importance for increasing crop production in stress affected areas. Therefore, we investigated the influence of $\mathrm{H}_{2} \mathrm{O}_{2}$ as a signal molecule by examining whether exogenous $\mathrm{H}_{2} \mathrm{O}_{2}$ pre-treatment could alleviate drought stress and its relations with antioxidant systems in two soybean cultivars differing in their sensitivity to drought. 


\section{MATERIALS AND METHODS}

\section{Growth of the plants and stress applications}

Two Glycine max L. cultivars sensitive to drought deficit in different levels (cv. Glycine max L. Merrill 537 (drought tolerant) and cv. Glycine max L. Merrill 520 (drought sensitive)) were used as the plant material. Seeds were surface sterilized with $0.1 \% \mathrm{HgCl}_{2}$ for $3 \mathrm{~min}$ followed by repeated washings with sterilized distilled water. Seeds were sown in plastic pots $(14 \mathrm{~cm}$ height, $16 \mathrm{~cm}$ top and $11 \mathrm{~cm}$ bottom diameter) containing soil and peat (5:1). Seedlings were grown in a phytotron (temperature: $23{ }^{\circ} \mathrm{C} \pm 2$, relative humidity: $60 \% \pm 5$ and light intensity: $400 \mu \mathrm{mol} \cdot \mathrm{m}^{-2} \mathrm{~s}^{-1}$ ) for 30 days. Four weeks after radicle emergence, either $1 \mathrm{mM} \mathrm{H}_{2} \mathrm{O}_{2}$ or distilled water was sprayed as foliar once daily for three days onto the leaves of each plant, and then irrigation was stopped. Treatments with $\mathrm{H}_{2} \mathrm{O}_{2}$ or distilled water were always followed by drought stress. Plants with no spray treatment and maintained irrigated throughout the experiment were used as control treatment. For measurements of all parameters, the leaves were collected at $4^{\text {th }}$ and $7^{\text {th }}$ days of drought after application and stored at $-80{ }^{\circ} \mathrm{C}$.

\section{Measurement of plant water status}

Leaf water potential $\left(\Psi_{\text {leaf }}\right)$ was measured with a thermocouple psychrometer at $27 \pm 1{ }^{\circ} \mathrm{C}$ (PSYPRO, Wescor, Inc., Logan, UT USA). Relative water content (RWC) in the leaves was determined according to Castillo [6]. Discs approximately $6 \mathrm{~mm}$ in diameter were cut from the youngest fully expanded leaves of plants and sealed in the C-52 psychrometer chamber. Samples were equilibrated for $60 \mathrm{~min}$ before the readings were recorded by a water potential data logger in the psychrometric mode. Values of leaf water potential were measured as MPa.

\section{Photosynthetic pigments}

Total chlorophyll (Chl) and carotenoid (Car) contents were determined following the method of Arnon [3]. Fresh leaf samples were selected randomly and homogenized in a mortar in $80 \%$ acetone. The extract was centrifuged at 5,000 $\mathrm{g}$ for $5 \mathrm{~min}$. Absorbance of the supernatant was recorded at 663, 645, and $450 \mathrm{~nm}$ by spectrophotometer.

\section{Antioxidant enzyme assays}

Enzyme extraction was carried out at $0-4{ }^{\circ} \mathrm{C}$. Frozen leaf segments $(0.5 \mathrm{~g})$ were crushed into fine powder in a mortar and under liquid $\mathrm{N} 2$. The leaf powder was homogenized in $5 \mathrm{ml}$ of $50 \mathrm{mM}$ potassium phosphate buffer ( $\mathrm{pH} 7.0$ ) containing $1 \mathrm{mM}$ EDTA and $1 \%$ polyvinylpyrrolidone (PVP), with the addition of $5 \mathrm{mM}$ ascorbic acid (ASC) in the 
case of the APX assay. The homogenate was centrifuged at $20,000 \mathrm{~g}$ for 20 min at $4{ }^{\circ} \mathrm{C}$ and the supernatant was used for the following enzyme assays.

Superoxide dismutase (SOD, EC 1.15.1.1) specific enzyme activity was measured $\left(25^{\circ} \mathrm{C}\right)$ based on the method of Beauchamp and Fridovich [4], as modified by Dhindsa and Matowe [8]. Catalase (CAT, EC 1.11.1.6) specific enzyme activity was determined by following the consumption of $\mathrm{H}_{2} \mathrm{O}_{2}\left(25^{\circ} \mathrm{C}, \mathrm{e}=39.4 \mathrm{mM}^{-1} \mathrm{~cm}^{-1}\right)$ at $240 \mathrm{~nm}$ [2]. Ascorbate peroxidase (APX, EC 1.11.1.11) specific enzyme activity was estimated by monitoring ascorbate oxidation at $290 \mathrm{~nm}\left(25^{\circ} \mathrm{C}, \mathrm{e}=2.8 \mathrm{mM}^{-1} \mathrm{~cm}^{-1}\right)$ [25]. Glutathione reductase (GR, EC 1.6.4.2) specific enzyme activity was determined by measuring the decrease in absorbance at $340 \mathrm{~nm}\left(25^{\circ} \mathrm{C}, \mathrm{e}=6.22 \mathrm{mM}^{-1} \mathrm{~cm}^{-1}\right)$ according to Foyer and Halliwell [9]. Monodehydroascorbate reductase (MDHAR, EC 1.6.5.4) specific enzyme activity was determined by following the oxidation of NADH at $340 \mathrm{~nm}$ [13]. Dehydroascorbate reductase (DHAR, EC 1.8.5.1) specific enzyme activity was assayed essentially as described before by Hossain and Asada [12]. The activity of each enzyme was expressed on a protein basis. Protein content was determined according to Bradford [5], using bovine serum albumin as standard.

\section{Lipid peroxidation}

Lipid peroxidation was measured in terms of malondialdehyde content $\left(\mathrm{e}=155 \mathrm{mM}^{-1}\right.$ $\mathrm{cm}^{-1}$ ), a product of lipid peroxidation following the method of Heath and Packer [11]. Leaf samples $(0.5 \mathrm{~g})$ were homogenized in $10 \mathrm{ml}$ of $0.1 \%(\mathrm{w} / \mathrm{v})$ trichloroacetic acid (TCA). $4 \mathrm{ml}$ of $0.5 \%(\mathrm{w} / \mathrm{v})$ thiobarbituric acid containing $20 \%(\mathrm{w} / \mathrm{v}) \mathrm{TCA}$ was added to $1 \mathrm{ml}$ aliquot of supernatant. The absorbance of the supernatant was recorded at 532 and $600 \mathrm{~nm}$ and the malondialdehyde (MDA) content was expressed as nmol MDA g- ${ }^{-1} \mathrm{FW}$.

\section{Hydrogen peroxide concentration}

Hydrogen peroxide concentration was determined according to a modified method of Velikova et al. [34]. Leaves $(0.25 \mathrm{~g})$ were ground in $3 \mathrm{ml}$ of $5 \%$ trichloroacetic acid with $0.1 \mathrm{~g}$ of activated charcoal at $0{ }^{\circ} \mathrm{C} .0 .5 \mathrm{ml}$ of $10 \mathrm{mM}$ potassium phosphate buffer ( $\mathrm{pH} \mathrm{7.0)}$ and $0.75 \mathrm{ml}$ of $1 \mathrm{M} \mathrm{KI}$ were added to $0.5 \mathrm{ml}$ aliquot of the supernatant. The absorbance was measured at $390 \mathrm{~nm}$ and $\mathrm{H}_{2} \mathrm{O}_{2}$ concentration was expressed as $\mu \mathrm{mol} \mathrm{g}^{-1} \mathrm{FW}$.

\section{Statistical analysis}

All analysis was repeated three times on a mixture of leaves from three individual plants with three technical replicates. Variance analysis of mean values was performed with the Duncan multiple comparison test using SPSS software for Microsoft Windows (Ver. 15.0, SPSS Inc., USA) and a significance level was determined at the $5 \%(\mathrm{P}<0.05)$ level. 


\section{RESULTS}

\section{Water status parameters}

We measured the leaf water potential of both cultivars during the drought period after $\mathrm{H}_{2} \mathrm{O}_{2}$ to understand how water status was affected by the treatment. $\Psi_{\text {leaf }}$ and RWC decreased in both cultivars during drought stress. However, $\mathrm{H}_{2} \mathrm{O}_{2}$ pre-treatment sustained the water potential and RWC of stressed plants at a higher level than drought
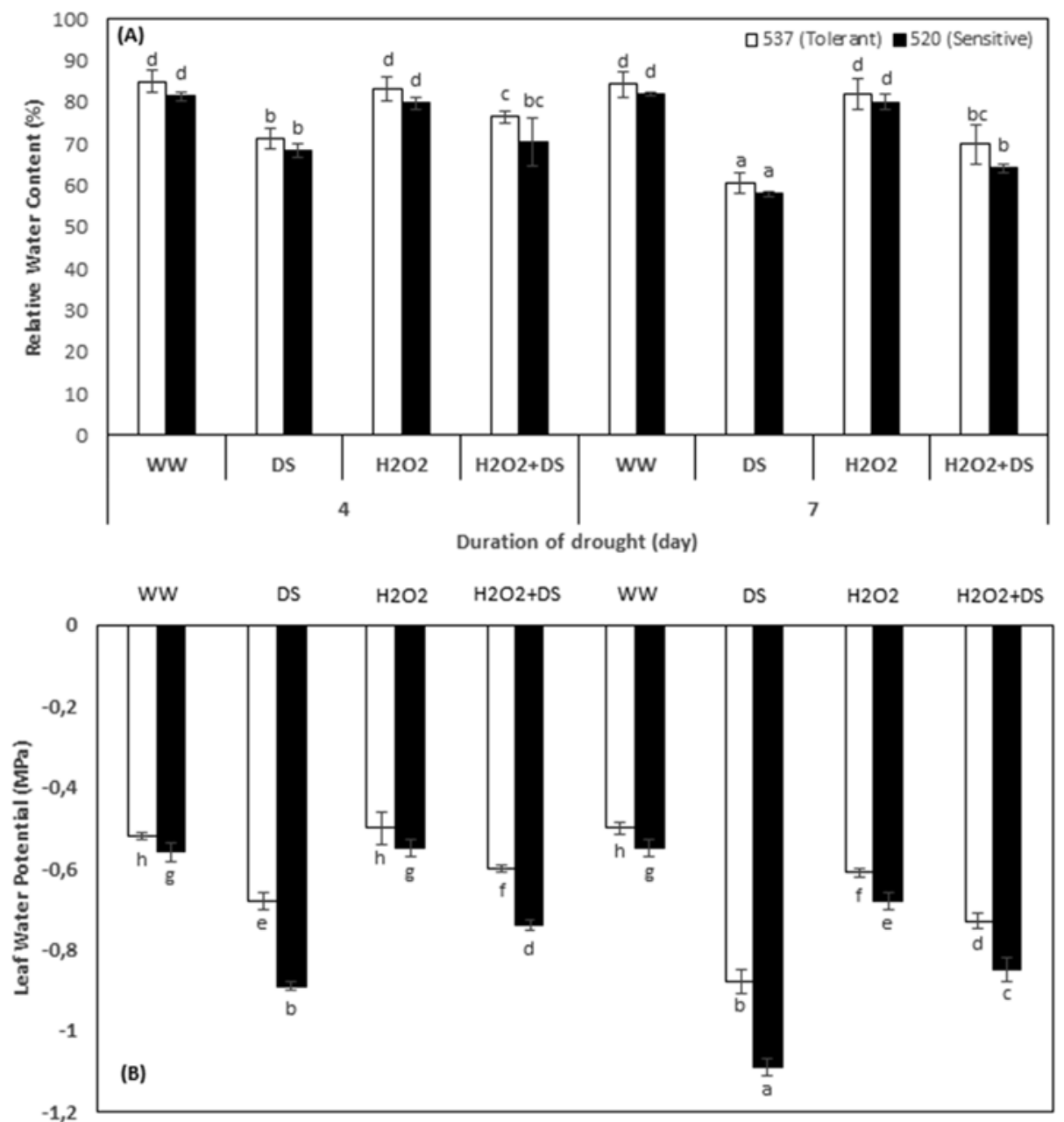

Fig. 1. Relative water content (A) and leaf water potential (B) and in two soybean cultivars [537 (tolerantopen square), 520 (sensitive-filled square)] treated with $\mathrm{H}_{2} \mathrm{O}_{2}$ during drought stress. WW, DS, $\mathrm{H}_{2} \mathrm{O}_{2}$ and $\mathrm{H}_{2} \mathrm{O}_{2}+$ DS are abbreviations of well-watered, drought stress hydrogen peroxide and hydrogen peroxide and drought stress. Vertical bars represent standard deviation. Different letters denote significant differences between the two cultivars along with different treatments at $\mathrm{P}<0.05$ 
treatment alone. In tolerant cultivar, $\Psi_{\text {leaf }}$ of drought treated plants were down from $-0.68 \mathrm{MPa}$ on the $4^{\text {th }}$ day to $-0.88 \mathrm{MPa}$ on the $7^{\text {th }}$ day of the drought period. Water potential of $\mathrm{H}_{2} \mathrm{O}_{2}$ treated plants were also down from $-0.60 \mathrm{MPa}$ to $-0.75 \mathrm{MPa}$ on the $4^{\text {th }}$ and $7^{\text {th }}$ days of the drought period (Fig. 1B). After pre-treatment with $\mathrm{H}_{2} \mathrm{O}_{2}, \mathrm{RWC}$ of tolerant cultivar were down from $85 \%$ to $76 \%$ and $69 \%$ on the $4^{\text {th }}$ and $7^{\text {th }}$ days of the drought period compared to the control plants, respectively (Fig. 1A). A similar trend of the $\Psi_{\text {leaf }}$ and RWC was also recorded in sensitive cultivar.
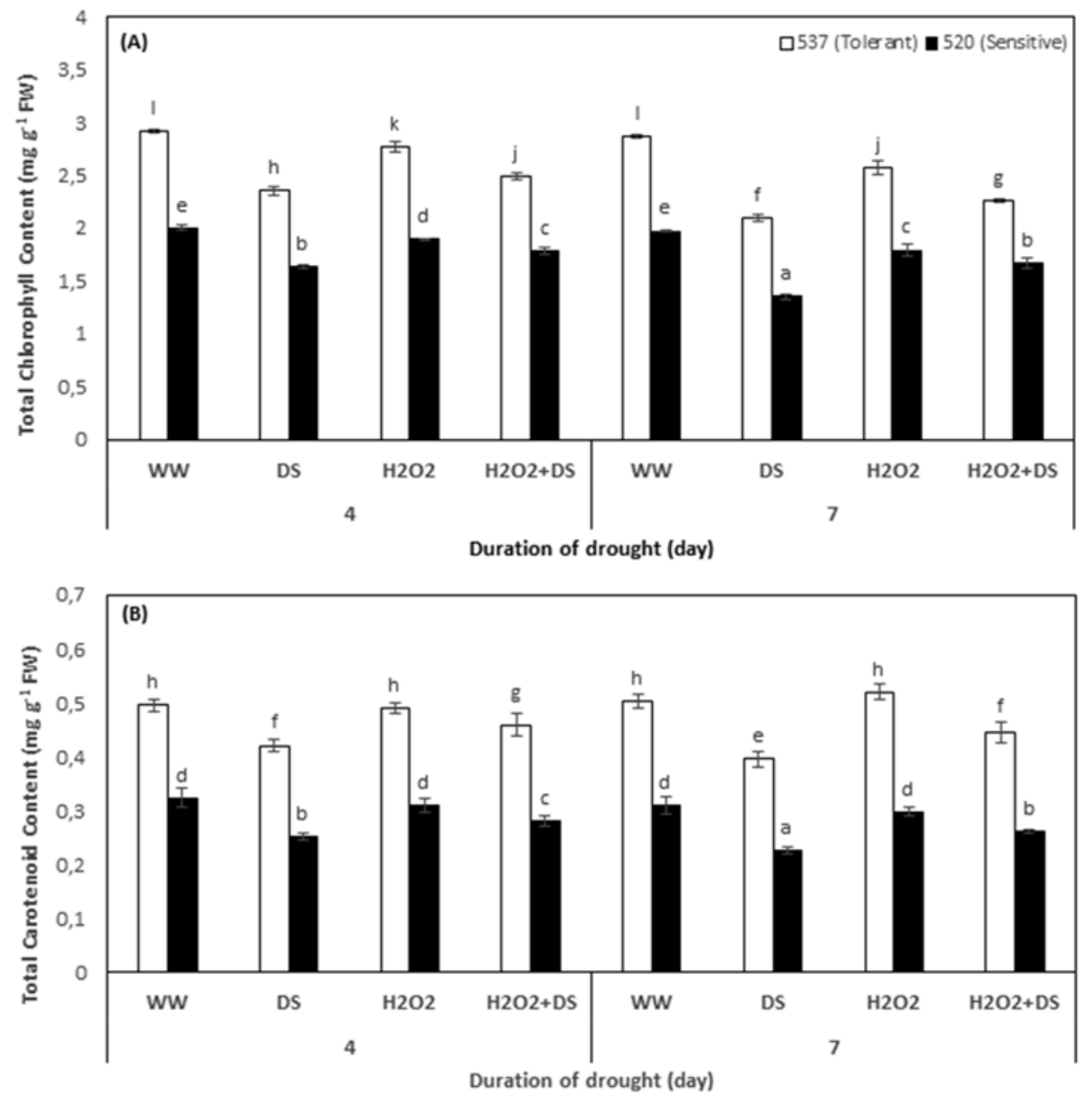

Fig. 2. Total chlorophyll (A) and total carotenoid (B) in two soybean cultivars [537 (tolerant-open square), 520 (sensitive-filled square)] treated with $\mathrm{H}_{2} \mathrm{O}_{2}$ during drought stress. WW, DS, $\mathrm{H}_{2} \mathrm{O}_{2}$ and $\mathrm{H}_{2} \mathrm{O}_{2}+$ DS are abbreviations of well-watered, drought stress hydrogen peroxide and hydrogen peroxide and drought stress. Vertical bars represent standard deviation. Different letters denote significant differences between the two cultivars along with different treatments at $\mathrm{P}<0.05$ 


\section{Photosynthetic pigments}

Drought stress significantly decreased total Chl content in both cultivars as compared to the control, which was greater in tolerant cultivar than in sensitive one. Exogenous $\mathrm{H}_{2} \mathrm{O}_{2}$ alone decreased total $\mathrm{Chl}$ content in both cultivars as compared to the control but the effect was not as high as in drought treatment alone. However, decrease in total Chl content was lower in $\mathrm{H}_{2} \mathrm{O}_{2}$-treated plants than drought treatment alone for both cultivars. After exogenous applications of $\mathrm{H}_{2} \mathrm{O}_{2}$, total $\mathrm{Chl}$ content of tolerant cultivar decreased by $15 \%$ and $27 \%$ on the $4^{\text {th }}$ and $7^{\text {th }}$ days of drought as compared to the control, but the reductions were $24 \%$ and $43 \%$ in drought treatment alone, respectively. A similar trend of the total Chl was also recorded in sensitive cultivar (Fig. 2A).

Compared to the control, total carotenoid (Car) in both cultivars was decreased at drought treatment alone and, this reduction was lower in the $\mathrm{H}_{2} \mathrm{O}_{2}$ pre-treated plants. Exogenous $\mathrm{H}_{2} \mathrm{O}_{2}$ alone did not change the total Car content in both cultivars as compared to the control. After exogenous applications of $\mathrm{H}_{2} \mathrm{O}_{2}$, total Car content of the tolerant cultivar decreased by $8 \%$ and $13 \%$ on the $4^{\text {th }}$ and $7^{\text {th }}$ days of drought as compared to the control but the decrements were $15 \%$ and $21 \%$ in drought treatment alone, respectively. A similar phenomenon was observed in sensitive cultivar, but the decrements were higher pronounced in that of tolerant cultivar (Fig. 2B).

\section{Antioxidant enzymes}

All antioxidant enzyme activities were increased during drought treatments in both cultivars, and this increment was higher in the $\mathrm{H}_{2} \mathrm{O}_{2}$ pre-treated plants. The degree of increase related to $\mathrm{H}_{2} \mathrm{O}_{2}$ pre-treatment was higher in the tolerant compared to the sensitive cultivar. In plants pre-treated with $\mathrm{H}_{2} \mathrm{O}_{2}$, SOD activity of tolerant cultivar increased by $93 \%$ and $190 \%$ on day 4 and 7 of the drought period compared to the control, respectively. In sensitive cultivar, the activity increased by $66 \%$ and $65 \%$ on the $4^{\text {th }}$ and $7^{\text {th }}$ days of the drought period, respectively. Moreover, exogenous $\mathrm{H}_{2} \mathrm{O}_{2}$ alone increased SOD activity in both cultivars as compared to the control but the effect was not as high as in drought treatment alone (Fig. 3A).

CAT activity in $\mathrm{H}_{2} \mathrm{O}_{2}$ treated plants increased during the drought period. After exogenous applications of $\mathrm{H}_{2} \mathrm{O}_{2}$, the CAT activity was increased by $49 \%$ and $120 \%$ in tolerant cultivar on the $4^{\text {th }}$ and $7^{\text {th }}$ days of the drought period compared to the control, respectively. In sensitive cultivar, the activity in $\mathrm{H}_{2} \mathrm{O}_{2}$ treated plants was increased by $79 \%$ and $98 \%$ (Fig. 3B).

The combination of $\mathrm{H}_{2} \mathrm{O}_{2}$ pre-treatment and drought stress resulted in an increase in APX activity in both cultivars. After $\mathrm{H}_{2} \mathrm{O}_{2}$ pre-treatment, APX activity increased by $106 \%$ and $194 \%$ in tolerant cultivar on the $4^{\text {th }}$ and $7^{\text {th }}$ days of the drought compared to the control, respectively. The activity increased by $41 \%$ and $99 \%$ in sensitive cultivar. On $7^{\text {th }}$ day of drought, exogenous $\mathrm{H}_{2} \mathrm{O}_{2}$ alone increased APX activity in both cultivars as compared to the control but did not change APX activity of sensitive cultivar on $4^{\text {th }}$ day of drought (Fig. 3C). 

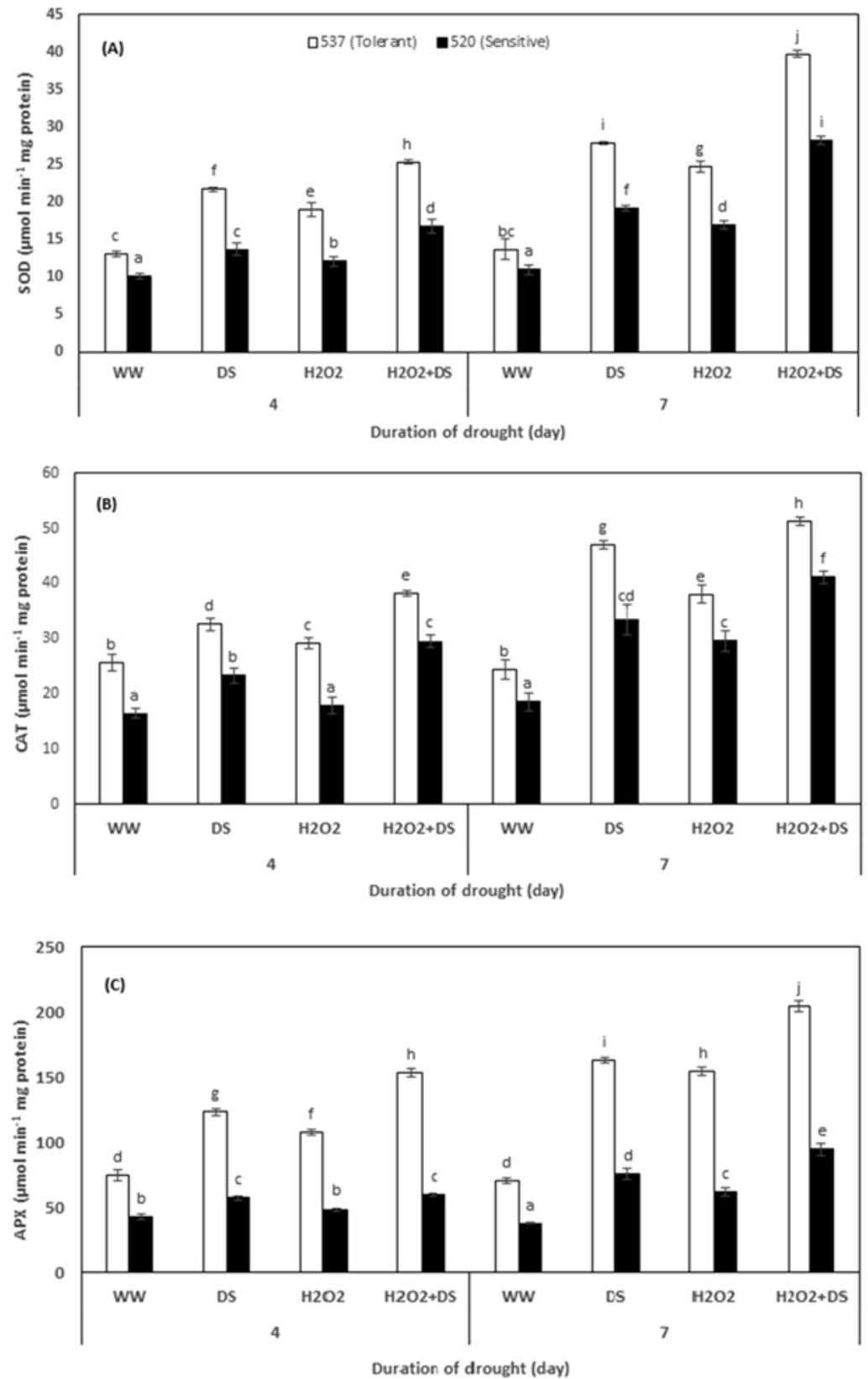

Fig. 3. Specific activities of antioxidant enzymes of superoxide dismutase (A), catalase (B), ascorbate peroxidase $(\mathrm{C})$, glutathione reductase (D), dehydroascorbate reductase (E) and monodehydroascorbate reductase (F) in two soybean cultivars [537 (tolerant-open square), 520 (sensitive-filled square)] treated with $\mathrm{H}_{2} \mathrm{O}_{2}$ during drought stress. WW, DS, $\mathrm{H}_{2} \mathrm{O}_{2}$ and $\mathrm{H}_{2} \mathrm{O}_{2}+\mathrm{DS}$ are abbreviations of well-watered, drought stress hydrogen peroxide and hydrogen peroxide and drought stress. Vertical bars represent standard deviation. Different letters denote significant differences between the two cultivars along with different treatments at $\mathrm{P}<0.05$ 


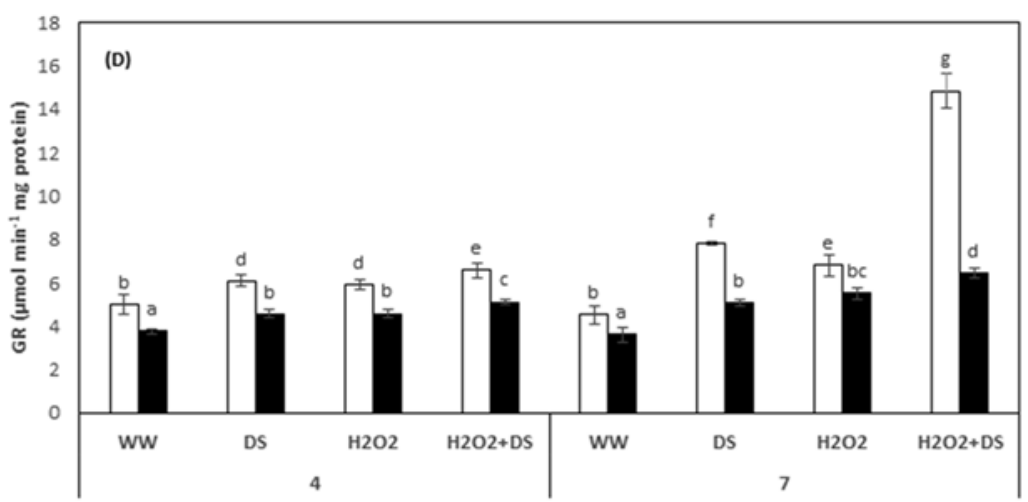

Duration of drought (day)
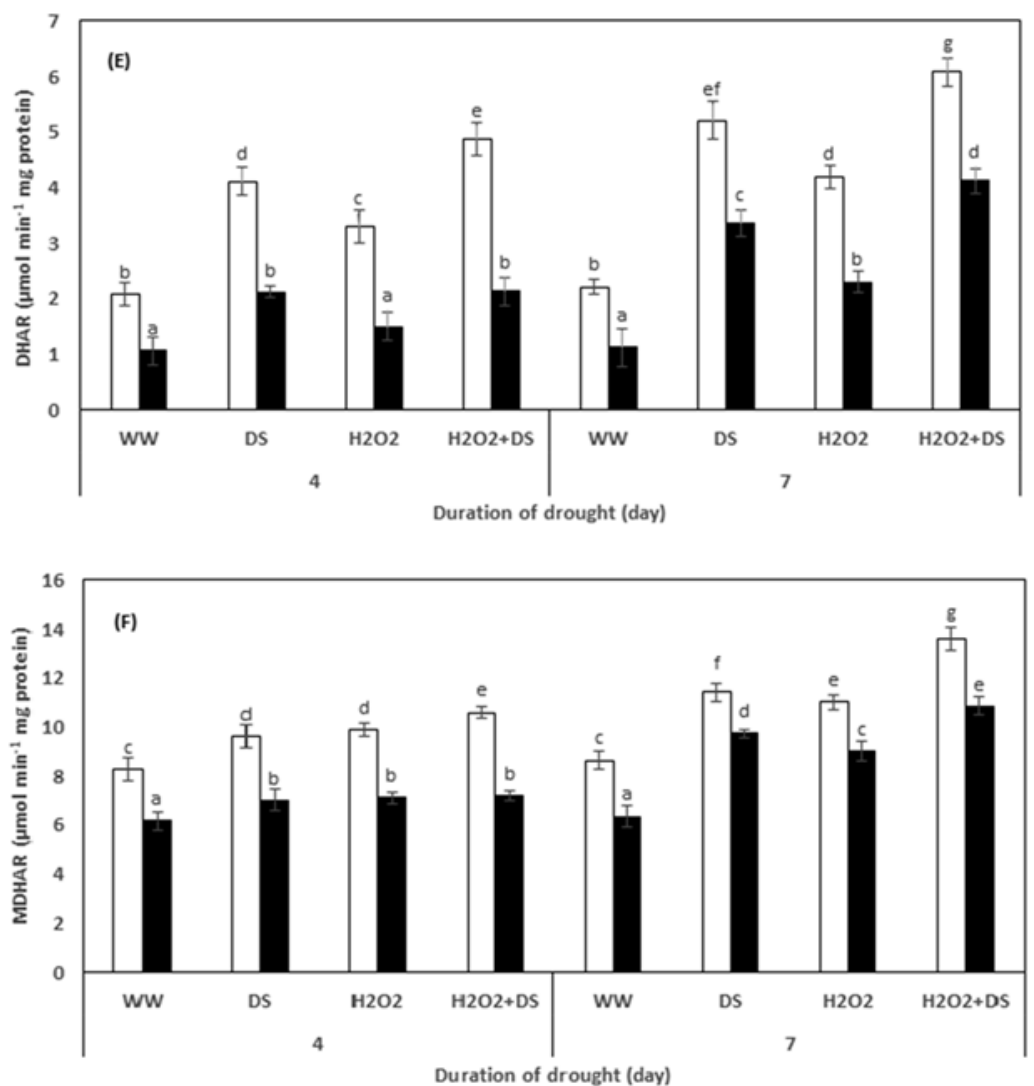

Fig. 3. (cont.) 
When compared with corresponding control, $\mathrm{H}_{2} \mathrm{O}_{2}$ pre-treatment significantly increased GR, DHAR and MDHAR activities in both cultivars under drought stress. In $\mathrm{H}_{2} \mathrm{O}_{2}$ treated drought stressed plants, all three enzyme activities were higher than those in the drought treatment alone (Fig. 3D, 3E, 3F). On the $4^{\text {th }}$ and $7^{\text {th }}$ days of the drought period, GR activity in $\mathrm{H}_{2} \mathrm{O}_{2}$-treated tolerant cultivar was increased by $31 \%$ and $229 \%$ but this increment was by $36 \%$ and $79 \%$ in sensitive cultivar. DHAR and MDHAR activities also showed a trend which is similar to GR activity (Fig. 3E, 3F).
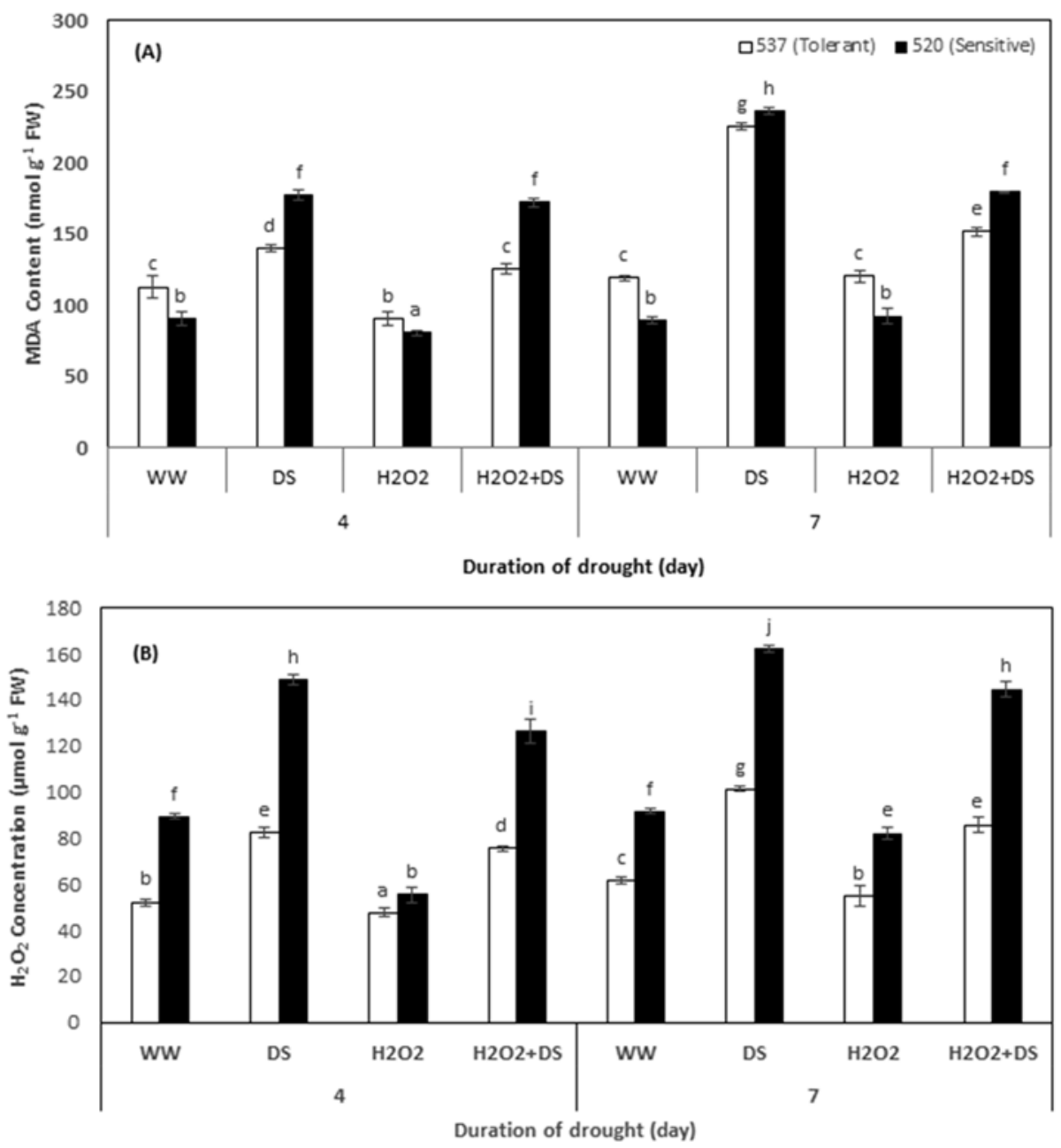

Fig. 4. Lipid peroxidation (A) and hydrogen peroxide (B) concentration in two soybean cultivars [537 (tolerant-open square), 520 (sensitive-filled square)] treated with $\mathrm{H}_{2} \mathrm{O}_{2}$ during drought stress. WW, DS, $\mathrm{H}_{2} \mathrm{O}_{2}$ and $\mathrm{H}_{2} \mathrm{O}_{2}+$ DS are abbreviations of well-watered, drought stress hydrogen peroxide and hydrogen peroxide and drought stress. Vertical bars represent standard deviation. Different letters denote significant differences between the two cultivars along with different treatments at $\mathrm{P}<0.05$ 


\section{Lipid peroxidation and $\mathrm{H}_{2} \mathrm{O}_{2}$ concentration}

As measured on $4^{\text {th }}$ and $7^{\text {th }}$ days of drought, lipid peroxidation increased during drought stress in both cultivars but sensitive cultivar showed a higher degree of peroxidation. Exogenous $\mathrm{H}_{2} \mathrm{O}_{2}$ alone decreased MDA content as compared to control on the $4^{\text {th }}$ day of drought but did not change on the $7^{\text {th }}$ day of drought. $\mathrm{H}_{2} \mathrm{O}_{2}$ pre-treatment also alleviated lipid peroxidation under drought stress (Fig. 4A).

Drought treatments resulted in higher $\mathrm{H}_{2} \mathrm{O}_{2}$ concentration in both cultivars as compared to well-watered plants, both on day 4 and 7. Exogenous $\mathrm{H}_{2} \mathrm{O}_{2}$ alone decreased endogenous $\mathrm{H}_{2} \mathrm{O}_{2}$ concentration in both cultivars as compared to the control. Exogenous application of $\mathrm{H}_{2} \mathrm{O}_{2}$ reduced $\mathrm{H}_{2} \mathrm{O}_{2}$ production caused by drought exposure in both cultivars, and this effect was more apparent in tolerant cultivar than in sensitive cultivar (Fig. 4B).

\section{DISCUSSION}

As signaling molecule in plants, $\mathrm{H}_{2} \mathrm{O}_{2}$ has been well reported to be involved in plant response to various environmental stresses. The present investigation suggests that exogenous application of $\mathrm{H}_{2} \mathrm{O}_{2}$ may help reduce adverse effects of drought in soybean cultivars. Maintenance of plant water status is a fundamental phenomenon for normal growth of plants under harsh environmental conditions. Relative water content and leaf water potential are the most important indicators of drought stress in plants and can be considered as an index for drought tolerance [29]. It is believed that $\mathrm{H}_{2} \mathrm{O}_{2}$ has the ability to improve plant water status $[17,33]$. The results of the present study showed that RWC and $\Psi_{\text {leaf }}$ declined in response to drought stress. On the other hand, $\mathrm{H}_{2} \mathrm{O}_{2}$ treated plants exhibited higher RWC and $\Psi_{\text {leaf }}$ during drought stress in compare with control plants. In other words, exogenous $\mathrm{H}_{2} \mathrm{O}_{2}$ treatment recovered leaf water status. Our findings demonstrated that improvement of water status following the exogenous application of $\mathrm{H}_{2} \mathrm{O}_{2}$ may be a result of alleviation of the detrimental effects of drought stress. Therefore, such an ameliorative effect on RWC and $\Psi_{\text {leaf }}$ may have been due to the role of $\mathrm{H}_{2} \mathrm{O}_{2}$ in osmotic adjustment and ensuring the accumulation of compatible solutes under drought stress conditions. Thus it could be deduced that $\mathrm{H}_{2} \mathrm{O}_{2}$ contributed to the stress acclimation of soybean cultivars. In a similar study, Ishibashi et al. [17] showed that RWC of drought-stressed leaves pretreated with $\mathrm{H}_{2} \mathrm{O}_{2}$ were higher than that of leaves pre-treated with distilled water. In addition, the same authors reported that exogenous application of $\mathrm{H}_{2} \mathrm{O}_{2}$ caused an increase in the mRNA levels of key enzymes for the biosynthesis of oligosaccharides, which are known to help plants tolerate drought stress. Gene expression changes in this manner enable soybean plant to become adapted and avoid drought stress through the maintenance of leaf water content. In another study, Terzi et al. [33] indicated that $\mathrm{H}_{2} \mathrm{O}_{2}$ pre-treated seedlings showed improved water status under osmotic stress, which induces osmotic stress tolerance by increasing soluble sugar, proline, and polyamine levels. On the other hand, exogenous $\mathrm{H}_{2} \mathrm{O}_{2}$ may be a stimulation of stoma- 
tal closure to reduce water loss. Indeed, literature contains numerous evidence that $\mathrm{H}_{2} \mathrm{O}_{2}$ is an essential signal in mediating stomatal closure induced by ABA under a variety of abiotic stresses, such as drought and salinity [18, 26, 27]. However, Ishibashi et al. [17] reported that leaf water retention by $\mathrm{H}_{2} \mathrm{O}_{2}$ spraying was probably due to the increased oligosaccharide biosynthesis rather than rapid stomatal closure.

In our experiment, drought stress led to a sharp decrease in the amount of photosynthetic pigments. Treatment with $\mathrm{H}_{2} \mathrm{O}_{2}$ alleviates the drought stress by improving pigment contents in both cultivars. Similar to our results, Abass and Mohamed [1] found that $\mathrm{H}_{2} \mathrm{O}_{2}$ treatment enhanced plant growth parameters and photosynthetic pigment content in common bean seedlings grown under drought conditions when compared with the seedlings of water treated seeds. Additionally, Liu et al. [23] showed that exogenous $\mathrm{H}_{2} \mathrm{O}_{2}$ protects the chloroplast ultrastructure under osmotic stress induced by PEG in two cucumber (Cucumis sativus L.) varieties. These findings demonstrate that $\mathrm{H}_{2} \mathrm{O}_{2}$ pre-treatment is a potential inducer to tolerate drought in plants by a great number of physiological processes and that this leads to better growth and development.

Lipid peroxidation is used to assess the extent of oxidative stress in plants, and its level increased under stress conditions [23]. In the present study, $\mathrm{H}_{2} \mathrm{O}_{2}$ pre-treatment prevented lipid peroxidation while the peroxidation increased in both cultivars under drought stress. According to presented results, exogenous low-dose $\mathrm{H}_{2} \mathrm{O}_{2}$ lowered level of lipid peroxidation and protected seedlings from oxidative damage. On the other hand, decrease in MDA content may be associated with the stimulation of antioxidant enzymes by low doses of $\mathrm{H}_{2} \mathrm{O}_{2}$. There were other reports suggesting exogenous $\mathrm{H}_{2} \mathrm{O}_{2}$ applications avoided the rising of MDA and endogenous $\mathrm{H}_{2} \mathrm{O}_{2}$ concentration in plants $[21,33,35]$.

Under stress conditions, the generation of ROS is a common phenomenon observed in most plants. Increasing ROS level causes oxidative damage to biomolecules such as lipids, proteins and nucleic acids [30]. In our work, drought stress caused accumulation of $\mathrm{H}_{2} \mathrm{O}_{2}$, but $\mathrm{H}_{2} \mathrm{O}_{2}$ concentration was effectively reduced by $\mathrm{H}_{2} \mathrm{O}_{2}$ pre-treatment in both cultivars. Similarly, Hossain and Fujita [14] examined the potential biochemical mechanisms of $\mathrm{H}_{2} \mathrm{O}_{2}$ treatment induced drought tolerance in mustard (Brassica juncea L.) seedlings and found that the concentration of endogenous $\mathrm{H}_{2} \mathrm{O}_{2}$ were markedly lower than that of seedlings subjected to drought stress without $\mathrm{H}_{2} \mathrm{O}_{2}$ pre-treatment in $\mathrm{H}_{2} \mathrm{O}_{2}$ pre-treated drought stressed-seedlings. A strong negative relationship of antioxidant enzymes with $\mathrm{H}_{2} \mathrm{O}_{2}$ concentration proved that $\mathrm{H}_{2} \mathrm{O}_{2}$ applications enhanced antioxidant enzymes activity, which resulted in scavenging effectiveness of $\mathrm{H}_{2} \mathrm{O}_{2}$. The data suggested that exogenous $\mathrm{H}_{2} \mathrm{O}_{2}$ might modulate plant defense responses to drought stress through the regulation of $\mathrm{H}_{2} \mathrm{O}_{2}$ production.

The activation of antioxidant system is an important adaptive strategy to reduce ROS production and minimize oxidative damage under stress conditions. In most cases, $\mathrm{H}_{2} \mathrm{O}_{2}$ seems to be positively used by plants to activate multiple stress-responsive genes that help plants cope with environmental challenges. Genes encoding antioxidant enzymes are central players in this network and their function has pro- 
found effects in controlling excessive ROS accumulation and cellular redox balance [15]. In this work, some antioxidant enzymes (SOD, APX, CAT, GR, MDHAR, DHAR) were studied in soybean cultivars in order to explain the role of exogenous low-dose $\mathrm{H}_{2} \mathrm{O}_{2}$ on the regulation of antioxidant defense in plants under drought stress. Based on the results, it has been clear that $\mathrm{H}_{2} \mathrm{O}_{2}$ induces antioxidant enzyme activities under drought stress more than that of the other groups did. Additionally, exogenous $\mathrm{H}_{2} \mathrm{O}_{2}$ pre-treatment further enhanced the activities of antioxidant enzymes in the tolerant cultivar compared to the sensitive cultivar. There are data supporting the claim that $\mathrm{H}_{2} \mathrm{O}_{2}$ increases the activity of antioxidant enzymes such as CAT, APX and SOD in cucumber seedlings and Ctenanthe setosa plants under osmotic stress $[23,28]$. According to our results, the higher activities of antioxidant enzymes in the $\mathrm{H}_{2} \mathrm{O}_{2}$ pre-treated plants coincide with a decrease in the concentration of endogenous $\mathrm{H}_{2} \mathrm{O}_{2}$, suggesting that $\mathrm{H}_{2} \mathrm{O}_{2}$ pre-treatment increases the ability of soybean cultivars to scavenge $\mathrm{H}_{2} \mathrm{O}_{2}$ via antioxidant enzymes under drought stress.

APX, MDHAR, DHAR and GR are also involved in the ASC-GSH cycle, which is an efficient antioxidant system for detoxifying $\mathrm{H}_{2} \mathrm{O}_{2}$ in the cell. Based on our data, there is also a trend in activities similar to that of the enzymes above in ASC-GSH cycle in both cultivars. These antioxidant enzyme activities in plants usually depend on antioxidant metabolites such as ascorbate, glutathione, tocopherol and polyphenols [20], especially ascorbate and glutathione play a key role in the redox signal transduction in higher plants under stress conditions [20]. Therefore, this metabolism might be partly responsible for higher antioxidant capacity. Our results showed that ASC-GSH cycle enzymes may act to remove produced $\mathrm{H}_{2} \mathrm{O}_{2}$ under drought stress. Thus, $\mathrm{H}_{2} \mathrm{O}_{2}$ may increase drought stress tolerance of soybean cultivars by promoting the activity of ASC-GSH cycle. At the same time, higher MDHAR, DHAR and GR activities were also observed in $\mathrm{H}_{2} \mathrm{O}_{2}$ treatments under osmotic stress, and increase in GR activity could promote the recycle of GSSG to GSH [10]. It is well known that ascorbate function greatly depends on its redox status which is closely related with MDHAR and DHAR specific enzyme activities, and increasing MDHAR and DHAR specific enzyme activities by exogenous $\mathrm{H}_{2} \mathrm{O}_{2}$ under osmotic stress has been important for the efficient antioxidant activity. Similarly, Hossain and Fujita [14] reported that $\mathrm{H}_{2} \mathrm{O}_{2}$ pre-treated seedlings maintained significantly higher APX, GR, CAT and GST activities, as well as a higher GSH/GSSG ratio compared with seedlings under drought only, which can activate ROS detoxification pathways and modulate the tolerance of seedlings to water deficit under drought stress.

In conclusion, water status and antioxidant enzymes activities were significantly enhanced by exogenous low-dose $\mathrm{H}_{2} \mathrm{O}_{2}$ pre-treatment in soybean cultivars under drought stress. When $\mathrm{H}_{2} \mathrm{O}_{2}$ treatment was combined with drought stress the level of endogenous $\mathrm{H}_{2} \mathrm{O}_{2}$ and MDA was reduced. However, exogenous $\mathrm{H}_{2} \mathrm{O}_{2}$ increased the antioxidant enzyme activities even more. An increased antioxidant capacity may, in turn, decrease the level of $\mathrm{H}_{2} \mathrm{O}_{2}$ in the cells. These findings indicate that application of $\mathrm{H}_{2} \mathrm{O}_{2}$ can help reduce the negative effects of drought stress by inducing antioxidant activity and decreasing $\mathrm{H}_{2} \mathrm{O}_{2}$ level and water loss to some extent and may have a key role in providing tolerance to soybean. 


\section{ACKNOWLEDGEMENTS}

This work was supported by the Research Unit of Recep Tayyip Erdogan University (BAP, 2010.102.03.3).

\section{REFERENCES}

1. Abass, S. M., Mohamed, H. I. (2011) Alleviation of adverse effects of drought stress on common bean (Phaseolus vulgaris L.) by exogenous application of hydrogen peroxide. Bangladesh J. Bot. 41, $75-83$.

2. Aebi, H. (1983) Catalase. In: Bergmeyer, H. (ed.) Methods of Enzymatic Analysis. Weinheim-Verlag Chemie, Weinheim., Vol. 3, pp. 273-277.

3. Arnon, D. I. (1949) Copper enzymes in chloroplasts, polyphenoloxidase in Beta vulgaris. Plant Physiol. 24, 1-15.

4. Beauchamp, C., Fridovich, I. (1971) Superoxide dismutase: improved assays and an assay applicable to acrylamide gels. Anal. Biochem. 44, 276-287.

5. Bradford, M. M. (1976) A rapid and sensitive method for the quantitation of microgram quantities protein utilizing the principle of protein-dye binding. Anal. Biochem. 72, 248-254.

6. Castillo, F. J. (1996) Antioxidative protection in the inducible CAM plant Sedum album L. following the imposition of severe water stress and recovery. Oecologia 107, 469-477.

7. Desikan, R., Mackerness, S. A. H., Hancock, J. T., Neill, S. J. (2001) Regulation of the Arabidopsis transcriptome by oxidative stress. Plant Physiol. 127, 159-172.

8. Dhindsa, R. S., Matowe, W. (1981) Drought tolerance in two mosses: correlated with enzymatic defence against lipid peroxidation. J. Exp. Bot. 32, 79-91.

9. Foyer, C. H., Halliwell, B. (1976) Presence of glutathione and glutathione reductase in chloroplast: a proposed role in ascorbic acid metabolism. Planta 133, 21-25.

10. Foyer, C. H., Noctor, G. (2011) Ascorbate and glutathione: the heart of the redox Hub. Plant Physiol. $155,2-18$.

11. Heath, R. L., Packer, L. (1968) Photoperoxidation in isolated chloroplast. I. Kinetics and stochiometry of fatty acid peroxidation. Arch. Biochem. Biophys. 125, 189-198.

12. Hossain, M. A., Asada, K. (1984) Purification of dehydroascorbate reductase from spinach and its characterization as a thiol enzyme. Plant Cell Physiol. 25, 85-92.

13. Hossain, M. A., Nakano, Y., Asada, K. (1984) Monodehydroascorbate reductase in spinach chloroplasts and its participation in regeneration of ascorbate for scavenging hydrogen peroxide. Plant Cell Physiol. 25, 385-395.

14. Hossain, M. A., Fujita, M. (2013) Hydrogen peroxide priming stimulates drought tolerance in mustard (Brassica juncea L.). Plant Gene Trait. 4, 109-123.

15. Hossain, M. A., Bhattacharjee, S., Armin, S. M., Qian, P., Xin, W., Li, H. Y., Burritt, D. J., Fujita, M., Tran, L. S. P. (2015) Hydrogen peroxide priming modulates abiotic oxidative stress tolerance: insights from ROS detoxification and scavenging. Front. Plant Sci., 6, 1-19.

16. Huang, M., Guo, Z. (2005) Responses of antioxidative system to chilling stress in two rice cultivars differing in sensitivity. Biol. Plantarum 49, 81-84.

17. Ishibashi, Y., Yamaguchi, H., Yuasa, T., Inoue, M. I., Arima, S., Zheng, S. H. (2011) Hydrogen peroxide spraying alleviates drought stress in soybean plants. J. Plant Physiol. 168, 1562-1667.

18. Kim, T. H., Maik, B., Hu, H. H., Noriyuki, N., Julian, I. S. (2010) Guard cell signal transduction network advances in understanding abscisic acid, $\mathrm{CO}_{2}$, and $\mathrm{Ca}^{2+}$ signaling. Annu. Rev. Plant Biol. 61, $56-91$.

19. Komatsu, S., Kuji, R., Nanjo, Y., Hiraga, S., Furukawa, K. (2012) Comprehensive analysis of endoplasmic reticulum-enriched fraction in root tips of soybean under flooding stress using proteomics techniques. J. Proteomics 77, 531-560. 
20. Ksouri, R., Megdiche, W., Debez, A., Falleh, H., Grignon, C., Abdelly, C. (2007) Salinity effects on polyphenol content and antioxidant activities in leaves of the halophyte Cakile maritima. Plant Physiol. Biochem. 45, 244-249.

21. Li, J. T., Qui, Z. B., Zhang, X. W., Wang, L. S. (2011) Exogenous hydrogen peroxide can enhance tolerance of wheat seedlings to salt stress. Acta Physiol. Plant. 33, 835-842.

22. Liu, F. L., Andersen, M. N., Jensen, C. R. (2003) Loss of pod set caused by drought stress is associated with water status and ABA content of reproductive structures in soybean. Funct. Plant Biol. 30, 271-280.

23. Liu, Z. J., Guo, Y. K., Bai, J. G. (2010) Exogenous hydrogen peroxide changes antioxidant enzyme activity and protects ultrastructure in leaves of two cucumber ecotypes under osmotic stress. J. Plant Growth Regul. 29, 171-183.

24. Mohammadi, P. P., Moieni, A., Hiraga, S., Komatsu, S. (2012) Organ-specific proteomic analysis of drought-stressed soybean seedlings. J. Proteomics 75, 1906-1923.

25. Nakano, Y., Asada, K. (1981) Hydrogen peroxide is scavenged by ascorbate-specific peroxidase in spinach chloroplasts. Plant Cell Physiol. 22, 867-880.

26. Neill, S. J., Desikan, R., Clarke, A., Hurst, R. D., Hancock, J. T. (2002) Hydrogen peroxide and nitric oxide as signaling molecules in plants. J. Exp. Bot. 53, 1237-1247.

27. Pei, Z. M., Murata, Y., Benning, G., Thomine, S., Klusener, B., Allen, G., Grill, E., Schroeder. J. I. (2000) Calcium channels activated by hydrogen peroxide mediate abscisic acid signaling in guard cells. Nature 406, 731-734.

28. Saglam, A., Kalaycioglu, E., Guven, F. G., Saruhan, N., Kadioglu, A., Demiralay, M. (2014) Hydrogen peroxide extends postharvest life of Ctenanthe setosa leaf cuts under osmotic stress by reducing leaf Rolling. Hort. Environ. Biotechnol. 55, 308-314.

29. Shaw, B., Thomas, T. H., Cooke, D. T. (2002) Responses of sugar beet (Beta vulgaris L.) to drought and nutrient deficiency stress. Plant Growth Regul. 37, 77-83.

30. Smirnoff, N. (1993) The role of active oxygen in the response of plants to water deficit and desiccation. New Phytol. 125, 27-58.

31. Smirnoff, N. (1998) Plant resistance to environmental stress. Curr. Opin. Biotech. 9, 214-219.

32. Sobhanian, H., Razavizadeh, R., Nanjo, Y., Ehsanpour, A. A., Jazii, F. R., Motamed, N., Komatsu, S. (2010) Proteome analysis of soybean leaves, hypocotyls and roots under salt stress. Proteome Sci. 8 , 19-33.

33. Terzi, R., Kadioglu, A., Kalaycioglu, E., Saglam, A. (2014) Hydrogen peroxide pretreatment induces osmotic stress tolerance by influencing osmolyte and abscisic acid levels in maize leaves. J. Plant Interact. 9, 559-565.

34. Velikova, V., Yordanov, I., Edreva, A. (2000) Oxidative stress and some antioxidant systems in acid rain-treated bean plants, protective role of exogenous polyamines. Plant Sci. 151, 59-66.

35. Wang, Y., Li, J. L., Wang, J. Z., Li, Z. K. (2010) Exogenous $\mathrm{H}_{2} \mathrm{O}_{2}$ improves the chilling tolerance of manilagrass and mascarenegrass by activating the antioxidative system. Plant Growth Regul. 61, 195-204. 